\title{
PENGEMBANGAN MODEL TRANSPORTASI SEIMBANG (BALANCE) DENGAN MODIFIED DISTRIBUTION (MODI) DENGAN ORDO 5X5 BERBASIS ANDROID
}

\author{
Yuliani Indrianingsih ${ }^{1}$, Dwi Nugraheny ${ }^{2}$, Dwi Andhika Putra ${ }^{3}$ \\ Departemen Informatika \\ Sekolah Tinggi Teknologi Adisutjipto Yogyakarta \\ yulistta@gmail.com ${ }^{1}$, henynug@gmail.com ${ }^{2}$
}

\begin{abstract}
The absence of rapid examination technique to study transportation model using Modified Distribution often learning process become less efficient and effective. To use Modified Distribution (MODI), the first must to found the first solution of transportation model. To find the first solution of this transportation model using Northwest Corner method then find optimum solution with Modified Distribution (MODI) method. Before that Modified Distribution method had built to application on desktop with [9], but it just to calculate optimum solution to find minimum cost of transportation model on matrix 3X3. On application have some suggestion for developer who want to develop it, like to change user interface to be interesting, expand matrix to $m X n$ (for example 5X5) and add some study case in application to guide user to done case of Operation Research to calculate optimum solution to find minimum cost on transportation model using Modified Distribution (MODI) method in the class. In this essay will be develop an application Modified Distribution (MODI) using Northwest Corner method to calculate first solution and Modified Distribution (MODI) to calculate optimum solution with matrix 5X5 which implemented on android in operating system minimum API 15: Android 4.0.3 (Ice Cream Sandwich). Application Modified Distribution (MODI) have interesting interface, give easy to access information, and get accurate results, this is established from testing with score average 83,77\%.
\end{abstract}

Keywords: Transportation model, Northwest Corner, Modified Distribution (MODI).

\section{Pendahuluan}

Metode Modified Distribution (MODI) merupakan salah satu materi yang diajarkan di mata kuliah Riset Operasi. Modified Distribution (MODI) ini merupakan salah satu metode solusi akhir yang digunakan untuk menghitung biaya optimal pada model transportasi. Sebelumnya metode Modified Distribution (MODI) ini telah dibangun menjadi sebuah aplikasi berbasis desktop oleh [9], namun pada aplikasi tersebut mempunyai batasan masalah hanya untuk perhitungan biaya optimal pada model transportasi dengan ordo 3X3 saja. Pada aplikasi tersebut juga terdapat saransaran bagi developer yang ingin mengembangkan aplikasi tersebut yaitu membuat tampilannya menjadi lebih menarik pada perhitungan Modified Distribution (MODI) diperluas menjadi ordo $\mathrm{m} \mathrm{x}$ $\mathrm{n}$ (misal 5X5) dengan menambahkan beberapa contoh kasus dalam program untuk dijadikan panduan bagi user dalam menyelesaikan kasus-kasus yang berkaitan dengan riset operasi yang terkait dengan perhitungan biaya optimal menggunakan metode Modified Distribution (MODI) di kelas. Aplikasi Modified Distribution (MODI) berbasis desktop tersebut terkadang menjadi kurang efisien karena dalam penyampaiannya di kelas harus membawa laptop dengan ukuran yang besar dan tidak bisa dibuka setiap saat karena harus menghidupkan laptop terlebih dahulu yang membutuhkan waktu untuk membuka aplikasi tersebut. Seperti yang telah dijelaskan, maka akan dikembangkan sebuah aplikasi Modified Distribution (MODI) pada android untuk membantu proses belajar menjadi lebih efektif dan efisien, membuat tampilan menjadi lebih menarik, 
perluasan ordo menjadi m x n (5X5), penambahan beberapa contoh kasus pada mata kuliah Riset Operasi sebagai panduan bagi user, dan dapat digunakan tanpa perlu menghidupkan laptop yang membutuhkan waktu dalam prosesnya.

\section{Metode Penelitian}

\subsection{Use Case Diagram}
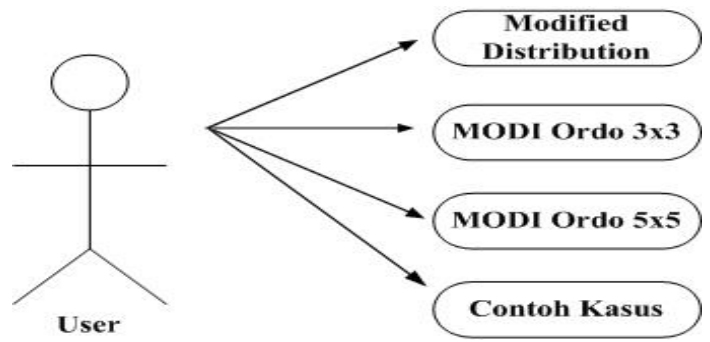

Gambar 1 Use Case Diagram dari aplikasi

Modified Distribution (MODI)

Pada Gambar 1 menjelaskan tentang Use Case Diagram dari aplikasi Modified Distribution (MODI) yang menunjukkan fungsional atau merepresentasikan sebuah interaksi antara user dengan sistem.

\subsection{Class Diagram}

Pada Gambar 2 yang menggambarkan struktur dan penjelasan class, paket, objek, dan hubungan antar class dalam sebuah sistem.

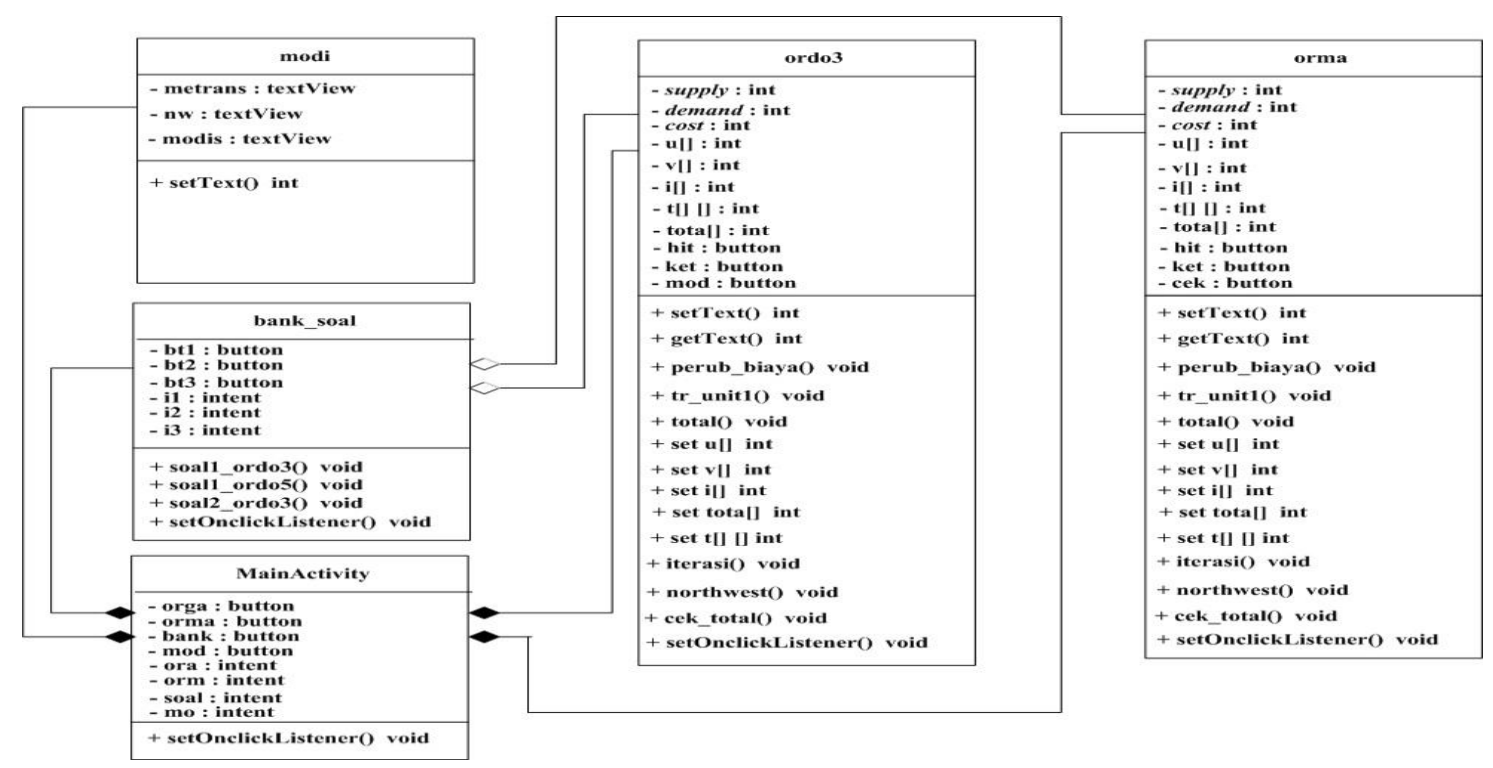

Gambar 2 Class Diagram aplikasi Modified Distribution (MODI)

\subsection{State Diagram}

Pada Gambar 3 merupakan state diagram dari aplikasi Modified Distribution (MODI) yang menggambarkan seluruh state yang memungkinkan objek-objek dalam suatu class. 


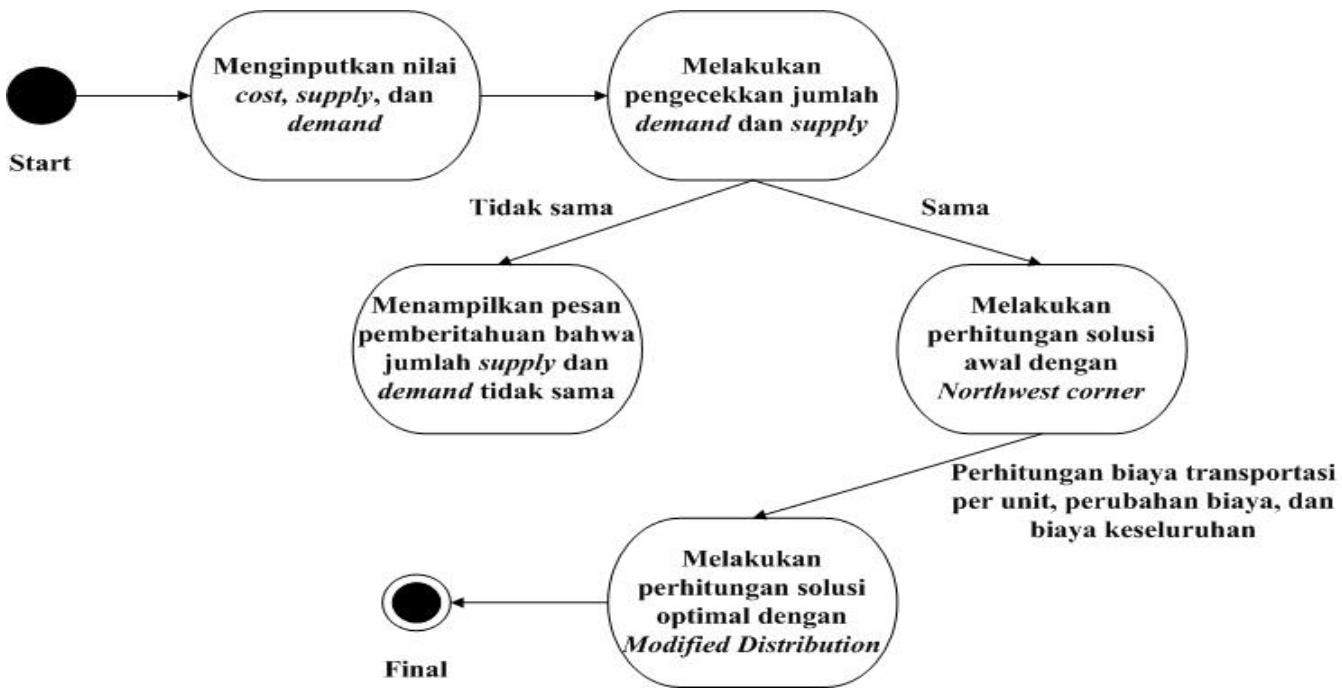

Gambar 3 State Diagram aplikasi Modified Distribution (MODI)

\subsection{Squence Diagram}

Pada Gambar 4 merupakan Squence Diagram dari aplikasi Modified Distribution (MODI) yang menggambarkan rangkaian objek-objek didalam sistem yang disusun secara urut sesuai dengan urutan rangkaian waktu.

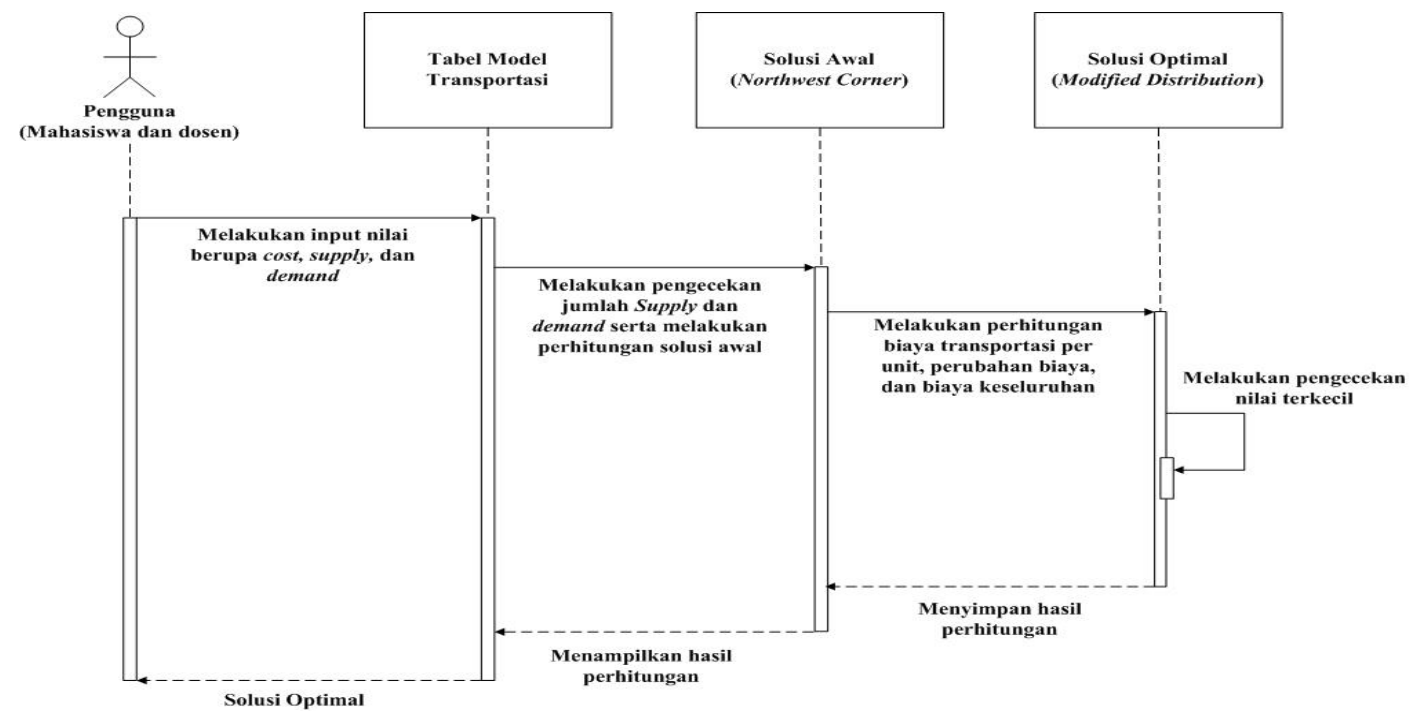

Gambar 4 Squence Diagram aplikasi Modified Distribution (MODI)

\subsection{Activity Diagram}

Pada Gambar 5 Activity Diagram dari aplikasi Modified Distribution (MODI) yang menggambrakan berbagai aktivitas dalam sistem yang telah dirancang mulai dari awal aktivitas yang terjadi sampai aktivitas berakhir. 


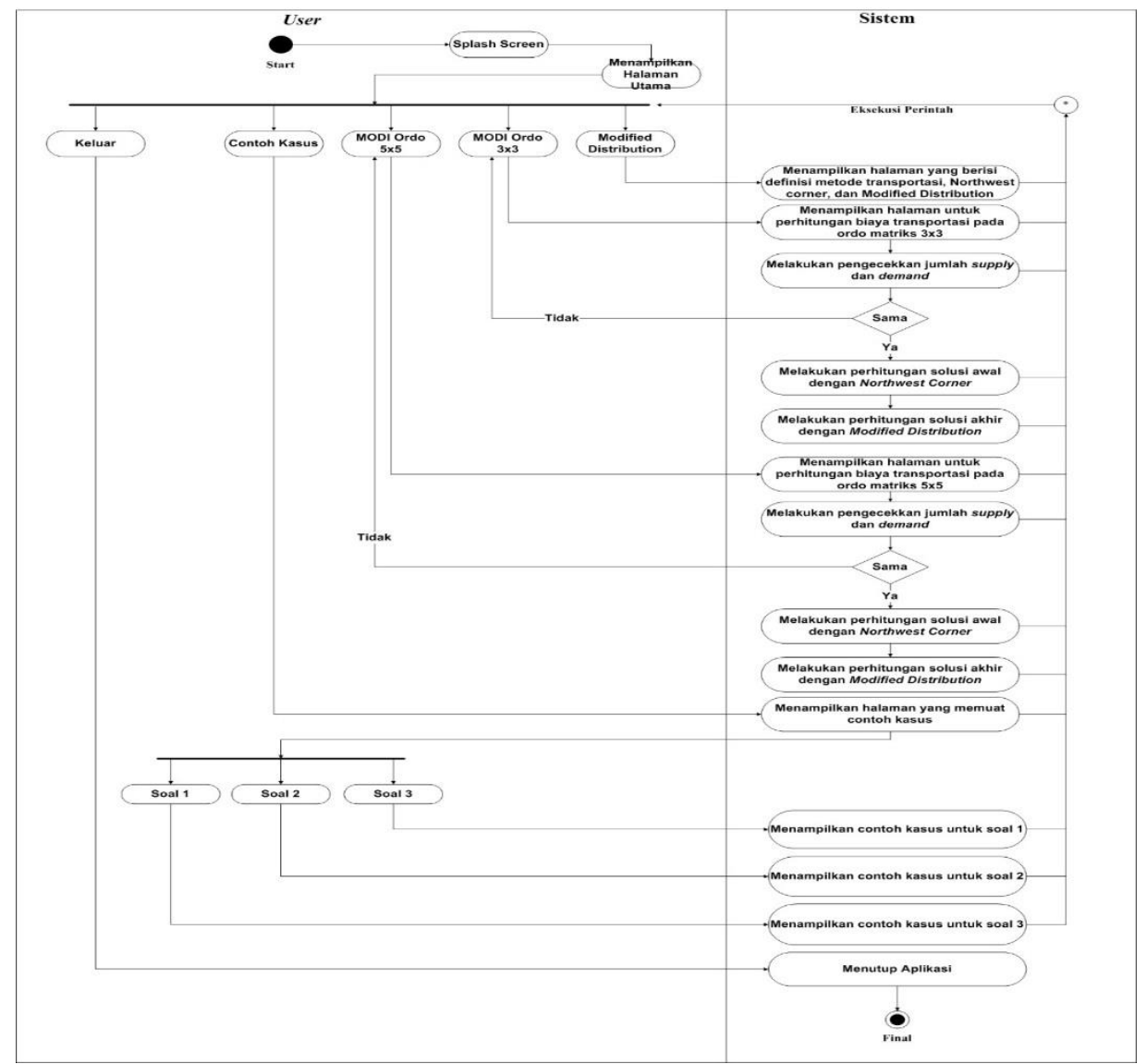

Gambar 5 Activity Diagram aplikasi Modified Distribution (MODI)

\section{Hasil dan Pengujian}

\subsection{Perhitungan dengan menggunakan aplikasi}

Suatu perusahaan mobil mempunyai 5 show room di lima tempat yang berbeda, yaitu P1, P2, P3, P4, dan P5 dengan penampungan masing-masing 250, 400, 450, 300, dan 100 buah/bulan. Mobil yang diproduksi dikirim kelima lokasi show room, yaitu T1, T2, T3, T4, dan T5 dengan permintaan penjualan masing-masing 180, 320, 370, 430, dan 200. Ongkos angkut dari masingmasing show room ke lokasi penjualan dapat dilihat pada tabel 1.

Tabel 1 Tabel soal

\begin{tabular}{|c|c|c|c|c|c|}
\hline & P1 & P2 & P3 & P4 & P5 \\
\hline T1 & 4 & 9 & 10 & 12 & 16 \\
\hline T2 & 4 & 3 & 10 & 5 & 8 \\
\hline T3 & 15 & 7 & 5 & 22 & 37 \\
\hline T4 & 24 & 21 & 18 & 12 & 6 \\
\hline T5 & 11 & 9 & 10 & 9 & 5 \\
\hline
\end{tabular}

Bagaimana cara perusahaan mengalokasikan pengiriman mobil dari lima show room ke lima lokasi penjualan agar biaya pengiriman minimum?. 


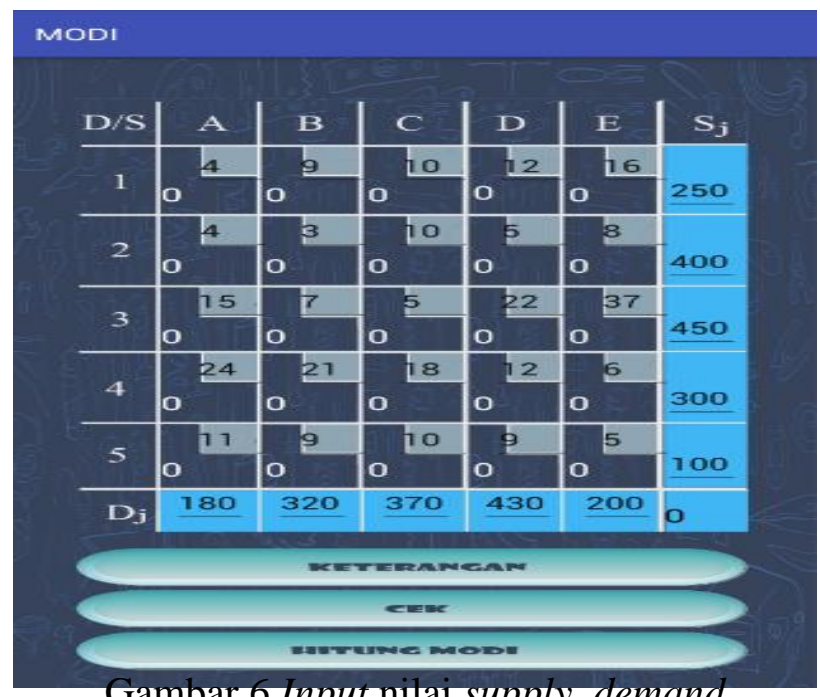

Gambar 6 Input nilai supply, demand dan biaya transportasi perunit

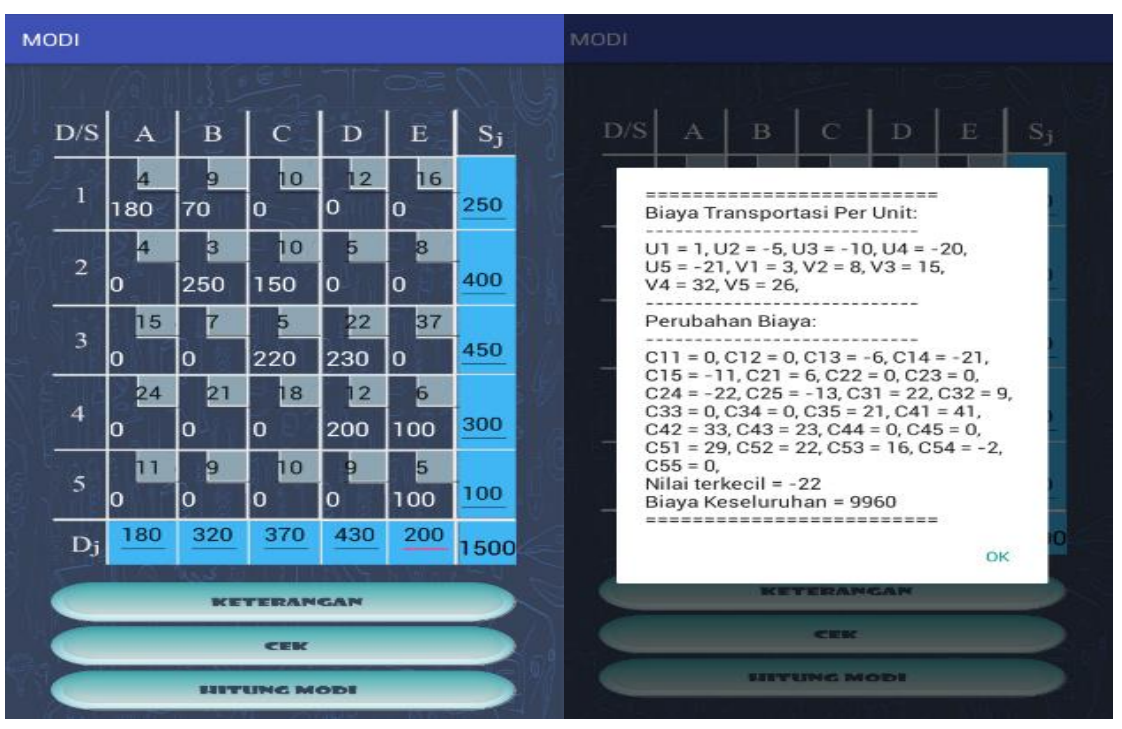

Gambar 7 Solusi awal, biaya transportasi per unit, dan perubahan biaya pada iterasi ke-0

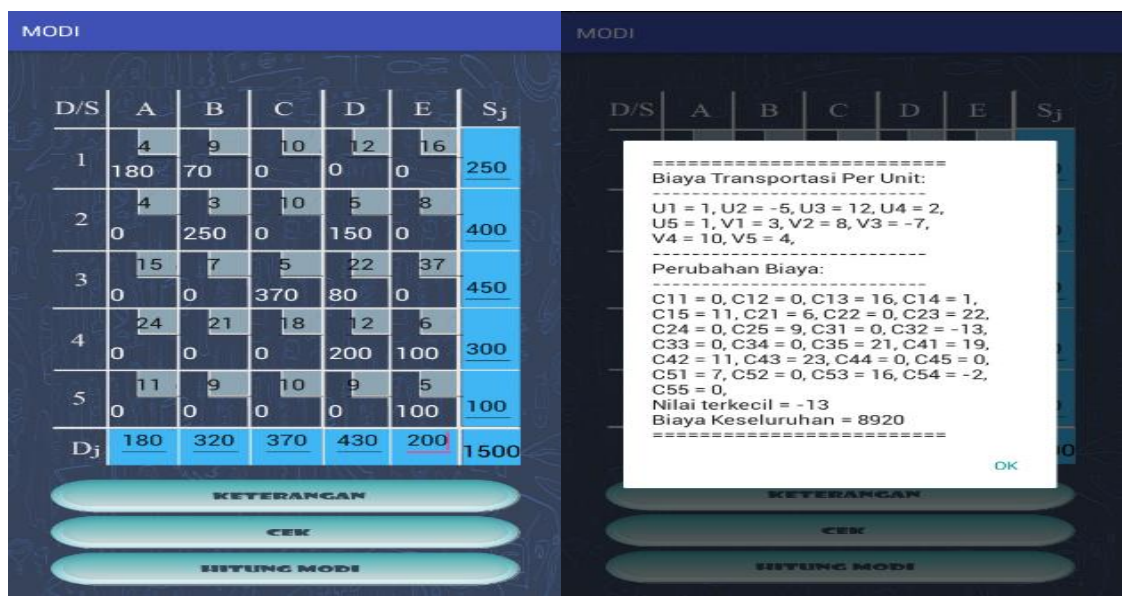

Gambar 8 Perubahan biaya, biaya transportasi per unit, dan indeks perbaikan pada iterasi ke-1 


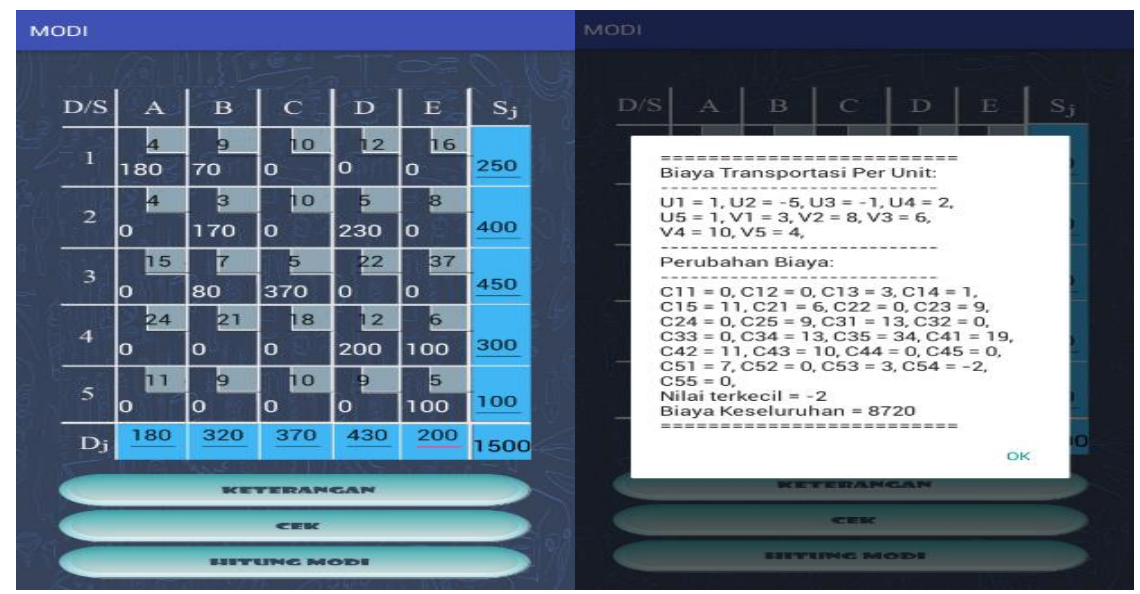

Gambar 9 Perubahan biaya, biaya transportasi per unit, dan indeks perbaikan pada iterasi ke-2

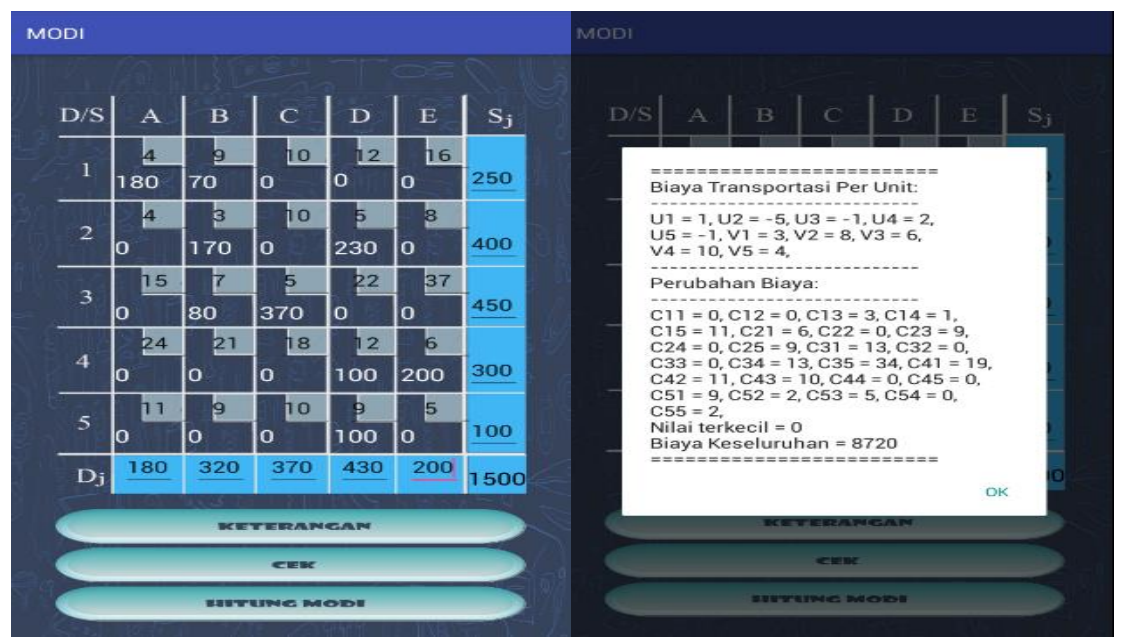

Gambar 10 Perubahan biaya, biaya transportasi per unit, dan indeks perbaikan pada iterasi ke-3

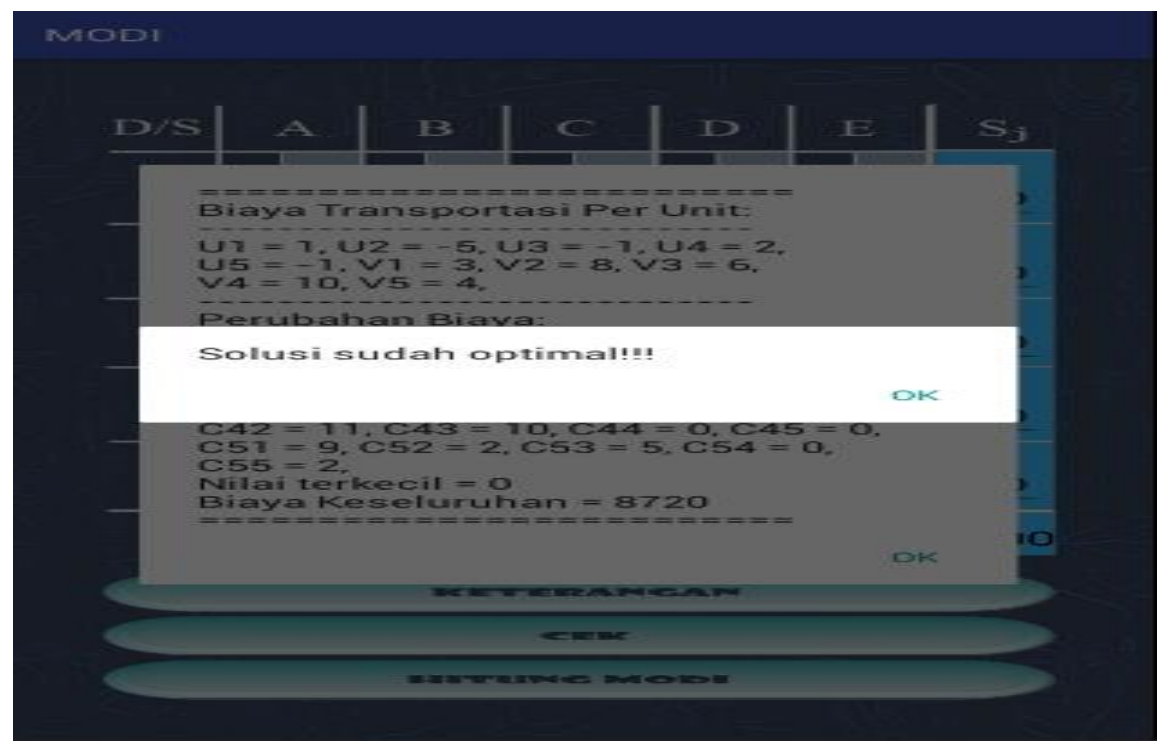

Gambar 11 Solusi optimal 


\subsection{Pengujian terhadap Sistem Operasi}

Berdasarkan tabel 2 didapatkan hasil bahwa pada device dengan sistem operasi API 10: Android 2.3 (Gingerbeard) terjadi kesalahan dalam menganalisa paket, sedangkan pada device dengan sistem operasi API 15 ke atas aplikasi berjalan dengan baik. Hal ini menunjukkan bahwa aplikasi Modified Distribution (MODI) berjalan pada sistem operasi minimal API 15: Android 4.0.3 (Ice Cream Sandwich).

Tabel 2 Tabel Pengujian Sistem Operasi

\begin{tabular}{|c|c|c|c|}
\hline No. & Device & Sistem Operasi & Keterangan \\
\hline 1 & Samsung GTS5360 & $\begin{array}{c}\text { API 10: Android } 2.3 \\
\text { (Gingerbeard) }\end{array}$ & $\begin{array}{c}\text { Ada masalah } \\
\text { menganalisa paket }\end{array}$ \\
\hline 2 & $\begin{array}{ll}\text { Advan } & \text { Vandroid } \\
\text { S5 } & \end{array}$ & $\begin{array}{l}\text { API 15: Android } 4.0 .3 \\
\text { (Ice Cream Sandwich) }\end{array}$ & $\begin{array}{c}\text { Berjalan dengan } \\
\text { baik }\end{array}$ \\
\hline 3 & OPPO JOY & $\begin{array}{c}\text { API 16: Android } 4.2 \\
\text { (Jelly Bean) }\end{array}$ & $\begin{array}{c}\text { Berjalan dengan } \\
\text { baik }\end{array}$ \\
\hline 4 & Asus Zenfone 4 & $\begin{array}{c}\text { API 19: Android 4.4.2 } \\
\text { (Kitkat) }\end{array}$ & $\begin{array}{c}\text { Berjalan dengan } \\
\text { baik }\end{array}$ \\
\hline 5 & Xiaomi Note 3 Pro & $\begin{array}{c}\text { API 21: Android 5.1.1 } \\
\text { (Lolipop) }\end{array}$ & $\begin{array}{c}\text { Berjalan dengan } \\
\text { baik }\end{array}$ \\
\hline 6 & Xiaomi Redmi 3S & $\begin{array}{c}\text { API 23: Android 6.0.1 } \\
\text { (Marsmallow) }\end{array}$ & $\begin{array}{c}\text { Berjalan dengan } \\
\text { baik }\end{array}$ \\
\hline
\end{tabular}

\section{Kesimpulan}

1. Aplikasi Modified Distribution (MODI) berjalan pada sistem operasi minimal API 15: Android 4.0.3 (Ice Cream Sandwich).

2. Tampilan aplikasi Modified Distribution (MODI) menarik dan nyaman untuk digunakan oleh user atau pengguna, memberikan kemudahan dalam akses informasi, dan dapat menghasilkan informasi yang akurat, hasil ini diperoleh melalui pengujian terhadap 35 orang responden pada kelas Riset Operasi dengan nilai rata-rata 83,77\% dengan kategori sangat baik.

3. Pada aplikasi Modified Distribution (MODI) telah dilakukan perluasan ordo menjadi $5 \times 5$, sehingga user atau pengguna dapat melakukan perhitungan biaya transportasi terendah dengan ordo matriks $3 \times 3$ dan $5 \times 5$, dengan hasil perhitungan yang tepat dan sesuai dengan hasil perhitungan manual, yang diperoleh dari hasil pengujian terhadap 35 responden.

4. Pada aplikasi Modified Distribution (MODI) telah dilakukan penambahan menu contoh kasus dengan harapan dapat memberikan panduan terhadap user atau pengguna untuk dijadikan acuan dan bahan belajar pada mata kuliah Riset Operasi.

5. Dengan aplikasi Modified Distribution (MODI) perhitungan biaya transportasi terendah menjadi lebih efisien dan efektif, dikarenakan user atau pengguna dapat setiap saat melakukan perhitungan dengan mudah tanpa harus membuka laptop atau menghidupkan komputer, hasil ini diperoleh dari pengujian terhadap 35 responden. 


\section{Daftar Pustaka}

[1] Ardiansyah, Firdan. 2011. Pengenalan Dasar Android Programming. Biraynara.

[2] Denis, Alan., Wixon, Barbara Haley., Tagarden, David. 2012. System Analysis and Design with UML Version 2.0: An Object-Oriented Approach Second Edition. Wiley

[3] Dewanto, I. Joko. 2006. Web Desain (Metode Aplikasi dan Implementasi). Yogyakarta: Graha Ilmu.

[4] Fathiyyah., Utama, I Gede Arya. 2008. Penerapan Metode Modified Distribution dalam Sistem Pendistribusian Barang pada PT. Miswak Utama. STIKOM Surabaya.

[5] Jogiyanto, HM. 2005. Analisis dan Desain. Bab 2. Hal. 41-52. Yogyakarta: ANDI.

[6] Murtiwiyati., Lauren, Glen. 2013. Rancang Bangun Aplikasi Pembelajaran Budaya Indonesia Untuk Anak Sekolah Dasar Berbasis Android. Jurnal Ilmiah Komputasi No. 2. Vol. 12.

[7] Nelwan, Claudia., Kekenusa, John S., Langi, Yohanes. 2013. Optimasi Pendistribusian Air dengan Mennggunakan Metode Least Cost dan Metode Modified Distribution (Studi Kasus: PDAM Kabupaten Minahasa Utara). 2013. Jurnal Ilmiah Sains No. 1. Vol. 13. Hal 45-50.

[8] Simbolon, Lolyta Damora., Situmorang, Marihat., Napitupulu, Normalina. 2014. Aplikasi Metode Transportasi dalam Optimasi Biaya Distribusi Beras Miskin (RASKIN) pada Perum Bulog Sub Divre Medan. Jurnal Ilmiah Sains Matematika. No. 03. Vol. 7. Hal. 90-94.

[9] Wahyu Sofyanti Dewi. 2015. Model Transportasi Menghitung Biaya Terendah Menggunakan Metode Modified Distribution. http://www.elib.stta.ac.id/elib/baca_pd f.php?file=11030063. pdf . Diakses pada hari senin tanggal 23 Januari 2017.

[10] Fathir. 2013. Cara Menghitung Skala Likert. https://fathirphoto.wordpress.com/ 2013/ 09/24/cara-menghitung-skala-likert. Diakses pada hari sabtu tanggal 25 Februari 2017. 